ISSN : $1412-7601$

Volume 3, No.1 Maret 2017

http://www.ekonobis.unram.ac.id

EKONOBIS

\title{
Praktik Gadai Lahan Dan Dampaknya Terhadap Kesejahteraan Al-Rahin Di Kecamatan Lingsar Kabupaten Lombok Barat
}

\author{
Ihsan Rois, M.Huzaini, Satarudin \\ Universitas Mataram
}

\section{ARTICLE INFO \\ Keywords : \\ Behavior, Pawn Practices} and Islamic Welfare
Kata Kunci :

Perilaku, Praktik Gadai dan

Kesejahteraan Islami
Received : 15 Des 2016; Accepted: 10 Februari 2017; Published: Maret 2017 ABSTRACT : This study aims to determine and analyze the factors that cause a person to pawn the land, how the implementation of mortgage, whether the practice of pawn is in accordance with Islamic law and how the level of welfare al-rahin in District Lingsar West Lombok regency. This study uses qualitative methods, because it examines the reality, phenomena or symptoms that are holistic / intact, complex, dynamic and full of meaning. Data collection techniques are carried out under natural conditions and carried out by means of observation, in-depth interviews and declarations of sound recording and photographs. The informant was set during the field using the snowball sampling technique. The data analysis used is qualitative analysis. The results of the research show that: 1 . Most farmers practice land pledge due to financial limitations and partly caused by dishonest dishonesty and to obtain business capital; 2 . The practice of pledge in Lingsar subdistrict is more characterized by custom which is a hereditary custom of its predecessors; 3 . The practice of pledge of land in Lingsar District is in accordance with the harmonious and pawning conditions according to Islam, but judging from the utilization of collateral goods is not in accordance with the principle of pledge according to Islam, because it gives birth to injustice between al-rahin and al-murtahin; 4. Most of the givers (al-rahin) in Lingsar sub-district have not been prosperous from the perspective of Islam, and the rest have mendapartkan welfare in Islam, because it has fulfilled the needs of dharuriyyat and hajiyatnya.

ABSTRAK : Penelitian ini bertujuan untuk mengetahui dan menganalisis faktor-faktor yang menyebabkan seseorang menggadaikan lahannya, bagaimana pelaksanaan gadai, apakah praktik gadai sudah sesuai dengan syariat Islam dan bagaimana tingkat kesejahteraan al-rahin di Kecamatan Lingsar Kabupaten Lombok Barat. Penelitian ini menggunakan metode kualitatif, karena meneliti realitas, fenomena atau gejala yang bersifat holistik/utuh, kompleks, dinamis dan penuh makna. Teknik pengumpulan data dilakukan pada kondisi yang alamiah dan dilakukan dengan cara observasi,wawancara mendalam dan dekumentasi berbentuk rekaman suara dan foto-foto. Informan ditetapkan selama berada di lapangan dengan menggunakan teknik snowball sampling. Analisis data yang digunakanadalah analisis kualitatif. Hasil Penelitian penelitian menunjukkan bahwa : 1. Sebagian besar petani melakukan praktik gadai lahan karena keterbatasan keuangan dan sebagaian lagi disebabkan oleh ketidak jujuran penggarapnya serta untuk mendapatkan modal usaha; 2. Praktik gadai yang ada di Kecamatan Lingsar lebih banyak diwarnai oleh adat yang merupakan kebiasaan yang turun temurun dari para pendahulunya; 3. Praktik gadai lahan yang ada di Kecamatan Lingsar sudah sesuai dengan rukun dan syarat gadai menurut Islam, namun kalau dilihat dari pemanfaatan barang jaminan belum sesuai dengan prinsip gadai menurut Islam, karena melahirkan ketidak-adilan antara al-rahin dan al-murtahin; 4. Sebagaian besar dari pemberi gadai (al-rahin) yang ada di Kecamatan Lingsar belum sejahtera dilihat dari perspektif Islam, dan sebagaiannya lagi sudah mendapartkan kesejahteraan secara Islam, karena sudah terpenuhi kebutuhan dharuriyyat dan hajiyatnya.

Corresponding Author:

Alamat : Program Studi Ekonomi Pembangunan, Fakultas Ekonomi dan Bisnis, Universitas Mataram, Jln. Majapahit No. 62 Mataram.

e-mail: ihsanrois@gmail.com 


\section{PENDAHULUAN}

\section{Latar Belakang}

Salah satu bentuk mu'amalah yang sifatnya saling tolong menolong sekaligus saling menguntungkan adalah rahn, yang dalam bahasa Indonesia diterjemahkan sebaga gadai. Pada dasarnya rahn merupakan aqad tabarru' (sukarela), yaitu upaya tolong menolong dan saling membantu antar sesama manusia dalam keadaan kesulitan, dan bukan merupakan kegiatan yang mengharapkan keuntungan. Hal ini sesuai dengan firman Allah (QS al-Baqarah [2] : 283)

Praktik menggadaikan lahan merupakan fenomena yang sering dijumpai dalam kehidupan masyarakat di Kabupaten Lombok Barat khususnya di Kecamatan Lingsar. Tuntutan kebutuhan yang mendesak menjadi alasan masyarakat untuk melakukan gadai lahan. Motivasi mereka melakukan gadai lahan bermacam-macam seperti untuk memenuhi kebutuhan-kebutuhan yang mendesak (untuk membayar biaya sekolah anak, modal ke Malaysia), menambah modal usaha atau membuka usaha baru yang lebih berpotensi untuk mendapatkan keuntungan, membeli lahan di tempat lain yang harganya lebih murah dan lain sebagainya.

Dari hasil observasi yang dilakukan, praktik gadai sawah yang ada di Kecamatan Lingsar kabupaten Lombok Barat secara kasap mata terlihat saling menguntungkan. Artinya si pemilik lahan dengan cepat dapat mendapatkan uang untuk memenuhi kebutuhannya, dan sipemilik uang dapat menginvestasikan kelebihan uangnya untuk tujuan yang lebih produktif. Akan tetapi proses gadai lahan ini telah berdampak pada ketidak adilan, terutama bagi yang mengadaikan lahannya. Hal ini terlihat dari hilangnya kesempatan pemilik lahan untuk memanfaatkan lahannya, sebelum ia dapat mengembalikan uang yang dipinjamnya dari pemilik uang. Hal ini berlangsung sampai batas waktu yang tidak ada batasnya. Implikasi dari kondisi ini adalah al-Murtahin dapat memanfaatkan lahan tersebut dengan mendapat keuntungan yang berlipat ganda bahkan melebih jumlah uang yang diberikan kepada al-rahin. Disinalah letak ketidakadilan yang diterima oleh al-rahin, sementara al-murtahin selalu mendapatkan keuntungan dari proses gadai tersebut.

Kesejahteraan merupakan tujuan akhir dari hidup setiap orang maupun sekelompok orang. Kata kesejahteraan merupakan suatu hal yang sangat subjektif, karena setiap orang mempunyai pandangan hidup, tujuan hidup dan cara hidup yang berbeda beda, maka nilai nilai yang diberikan kepada faktor-faktor yang menentukan tingkat kesejahteraan merekapun berbeda-beda pula. Penetapan nilai-nilai yang digunakan oleh manusia dalam menentukan tingkat kesejahteraannya dipengaruhi oleh berbagai faktor seperti letak geografis, nilai-nilai lokal, kekayaan dan lain-lain.

Berdasarkan uraian pada latar belakang dalam penelitian ini disusun judul penelitian sebagai berikut "Praktik Gadai Lahan dan Dampaknya terhadap Kesejahteraan al-Rahin di Kecamatan Lingsar Kabupapaten Lombok Barat”

\section{Tujuan Penelitian}

Berdasarkan uraian latar belakang, judul dan rumusan masalah, maka disusunlah tujuan penelitian sebagai berikut :

1. Untuk mengetahui dan menganalisis faktor-faktor yang menyebakan seseorang menggadaikan lahannya di Kecamatan Lingsar Kabupaten Lombok Barat.

2. Untuk mengetahui dan menganalisis pelaksanaan gadai lahan di Kecamatan Lingsar Kabupaten Lombok Barat.

3. Untuk mengetahui dan menganalisis apakah praktik gadai lahan sudah sesuai dengan syariat Islam di Kecamatan Lingsar Kabupaten Lombok Barat.

4. Bagaimana tingkat kesejahteraan alrahin (yang menyerahkan barang gadai) di Kecamatan Lingsar Kabupaten Lombok Barat.

\section{TINJAUAN PUSTAKA}

\section{Pengertian Gadai.}

Menurut Muhammad Abu Bakar ar Razi, Mukhtar as Shihah, Kairo, Dar al Hadits 
2002, hlm. 151 (dalam an Najah , 2010), Gadai dalam bahasa Arab dikenal dengan istilah al-tsubut (yang berarti tetap) dan alhabs (yang berarti tahanan).

Hal ini sesuai denga firman Allah (QS alMudatstsir [74] : 38)

"Tiap-tiap diri bertanggung jawab (tertahan) atas apa yang telah diperbuatnya".

Adapun gadai secara istilah bisa diartikan : pinjam meminjam barang dengan batas (bila telah sampai waktunya tidak ditebus, barang tersebut menjadi hak orang yang member pinjaman (Purwadarminta, 1995 : 286).

Menurut al Khatib asy Sarbini, Mughni al Muhtaj, Beirut Dar al Kutub al IImiyah

juz $3 \mathrm{hlm} 38$ (dalam an Najah, 2010), selanjutnya dalam literatur fiqh, gadai (arRahn) diartikan dengan : menjadikan barang sebagai barang jaminan dari hutang, sebagai pengganti jika hutang tersebut tidak dibayar.

Menurut Mazhab Hanabilah, Gadai adalah harta yang dijadikan jaminan utang sebagai pembayar harga (nilai) utang ketika kreditur berhalangan (tidak mampu) membayar utangnya kepada debitur.

Sedangkan menurut Mazhab Syafi'yah, Gadai adalah menjadikan suatu benda sebagai jaminan utang yang dapat dijadikan pembayar ketika berhalangan dalam membayar hutang.

Dari dua definisi di atas dapat disimpulkan bahwa Gadai (al-rahn) adalah menjadikan suatu barang sebagai jaminan atau agunan terhadap utang yang dilakukan oleh seorang kreditur kepada debitur.

\section{Sifat dan Landasan Hukum.}

Sifat :

Al-Rahn dikatagorikan sebagai akad yang bersifat derma, sebab apa yang diberikan penggadai (al-murtahin) tidak ditukar dengan sesuatu. Al-Rahin disebut juga sebagai akad ainiyah, yaitu dikatakan sempurna sesudah menyerahkan benda yang dijadikan akad, seperti hibah, pinjam meminjam, titipan dan qardl. Sesuai dengan kaidah fiqhiyah, sempurnanya suatu akad tabarru' setelah penyerahan barang.

\section{Landasan Hukum}

Al-rahn disyariatkan berdasarkan dalil alQur'an (QS al-Baqarah [2] : 283)

Jika kamu dalam perjalanan (dan bermu'amalah tidak secara tunai) sedang kamu tidak memperoleh seorang penulis, maka hendaklah ada barang tanggungan yang dipegang ${ }^{[180]}$ (oleh yang berpiutang). Akan tetapi jika sebagian kamu mempercayai sebagian yang lain, maka hendaklah yang dipercayai itu menunaikan amanatnya (hutangnya) dan hendaklah ia bertakwa kepada Allah Tuhannya; dan janganlah kamu (para saksi) menyembunyikan persaksian. Dan barangsiapa yang menyembunyikannya, maka sesungguhnya ia adalah orang yang berdosa hatinya; dan Allah Maha Mengetahui apa yang kamu kerjakan.

Hadits :

Rasulullah shallallahu 'alaihi wassallam pernah membeli makanan dari seorang Yahudi dengan cara tempo, lalu beliau menggadaikan baju perangnya yang terbuat dari besi ( HR Muslim)

\section{Rukun dan Syarat Gadai.}

1. Aqid (al-Rahin dan al-Murtahin) keduanya harus memenuhi syarat alahliyah (al-Syafi'iyah : aqil dan mumayyiz ; Hanafiyah : Aqil dan baligh)

2. Shighat (ijab-qabul) : syaratnya tidak boleh ada persyaratan atau dikaitkan dengan sesuatu.

3. Marhun bih (utang) menurut Hanabilah dan Syafi'iyah :

a.Berupa utang tetap dan dapat dimanfaatkan

b.Utang harus lazim pada saat akad

c.Utang harus jelas dan diketahui oleh rahin dan murtahin

4.Marhun (agunan/borg) : Menurut Hanafiah syaratnya : a. dapat diperjual belikan; b. Bermanfaat; c. Jelas; d. Milik rahin; e. Bisa diserahkan; f. Tidak bersatu denga harta lain; g. Dikuasai (dipegang) oleh rahin;h. Harta yang tetap ('uqar) atau harta bergerak (ghairu 'uqar)

\section{Teori Pertukaran Sosial (Social Exchange Theory)}

Tokoh yang mengembangkan teori pertukaran sosial antara lain adalah psikolog John Thibaut dan Harlod Kelley (1959), sosiolog George Homans (1961), 
Richard Emerson (1962), dan Peter Blau (1964). Berdasarkan teori ini, kita masuk ke dalam hubungan pertukaran dengan orang lain karena dari padanya kita memperoleh imbalan (Mustafa, 2009 : 9).

Teori pertukaran sosial mengatakan perilaku individu dengan lingkungan terdapat hubungan yang saling mempengaruhi (reciprocal). Dalam hubungan tersebut terdapat unsur imbalan (reward), pengorbanan (cost) dan keuntungan (profit). Imbalan merupakan segala hal yang diperoleh melalui adanya pengorbanan, pengorbanan merupakan semua hal yang dihindarkan, dan keuntungan adalah imbalan dikurangi oleh pengorbanan. Jadi perilaku sosial terdiri atas pertukaran paling sedikit antar dua orang berdasarkan perhitungan untungrugi. Jadi perilaku seseorang dimunculkan karena berdasarkan perhitungannya, akan menguntungkan bagi dirinya, demikian pula sebaliknya jika me-rugikan maka perilaku tersebut tidak ditampilkan (Homans dalam Mustafa, 2009 : 9).

\section{Kesejahteraan Islami}

Menurut al-Syathibi dalam Muflih, (2006: $66)$, rumusan kebutuhan manusia dalam Islam terdiri dari tiga jenjang, yaitu : dharuriyat, hajiyat dan tahsiniah, dimana ketiga komponen ini saling terkait satu sama lain yang tidak

dapat dipisahkan. Tiga jenjang tersebut adalah :

1. Dharuriyat, yang mencakup Din (agama), Nafs (kehidupan),'Aql (pendikan), Nasl (keturunan), dan Mal (harta).

2. Hajiyat, jenjang ini merupakan pelengkap yang mengokohkan, menguatkan dan melindungi jenjang dharuriyyat.

3. Tahsiniyat, jenjang ini merupakan penambah bentuk kesenangan dan keindah an dharuriyat dan hajiyat.

Lima kebutuhan dharuriyat (esensial) yang mencakup din, nafs, 'aql, nasl dan mal merupakan satu kesatuan yang tak dapat dipisahkan. Apabila ada satu jenis yang sengaja diabaikan, akan menimbulkan ketimpangan dalam hidup manusia. Manusia hanya akan dapat melangsungkan hidupnya dengan baik jika kelima macam kebutuhan itu terpenuhi dengan baik pula.

\section{METODE PENELITIAN}

Penelitian ini menggunakan metode kualitatif, karena meneliti realitas, fenomena atau gejala yang bersifat holistik/utuh, kompleks, dinamis dan penuh makna. Kegiatan penelitian ini dilakukan di Kecamatan Lingsar Kabupaten Lombok Barat.

Pengumpulan data primer dilakukan pada kondisi yang alamiah, tehnik pengumpulan data dilakukan dengan cara observasi partisipatif, wawancara mendalam dan teknik dokumentasi dalam bentuk rekaman suara, foto dan beberapa dekumen visual lainnya. Informan dalam penelitian ini adalah petani yang melakukan praktik gadai. Informan dipilih terlebih dahulu sebelum peneliti turun lapangan dan selama berada di lapangan, dengan menggunakan tehnik "snowball sampling". Analisis data yang digunakan adalah analisis kualitatif yang meliputi reduksi data, display data, dan menarik kesimpulan

\section{HASIL DAN PEMBAHASAN.}

\section{Beberapa Alasan Masyarakat Menggadaikan Lahan.}

Praktik gadai yang dilakukan oleh masyarakat di Kecamatan Lingsar Kabupaten Lombok Barat sebahagian besar disebabkan oleh adanya kebutuhan akan dana yang mendesak seperti untuk membayar uang sekolah/kuliah putra-putri mereka, untuk membayar hutang dan untuk modal pergi ke Malaysia. Selain alasan di atas masyarakat petani melakukan gadai lahan disebabkan juga oleh faktor kejengkelan kepada penggarapnya yang tidak jujur. Dari informasi yang didapatkan dari yang menggadaikan lahannya, penggarap seolah olah menganggap tanah garapannya merupakan miliknya, sehingga dia berperilaku seperti pemilik, padahal setatusnya sebagai penggarap. Akhirnya pemilik lahan mengambil keputusan untuk menggadaikan lahannya, ketimbang tidak /kurang dapat hasil dari 
lahan tersebut. Hal lain yang menyebabkan mengapa masyarakat petani mengadaikan lahannya adalah utuk menambah modal usaha, baik pada skala mikro maupun menengah kecil.

\section{Praktik gadai lahan di Kecamatan Lingsar Kabupaten Lombok Barat.}

Praktik gadai lahan yang dilakukan oleh masyarakat di Kecamatan Lingsar Kabupaten Lombok Barat, mengacu pada adat kebiasaan yang terjadi di masyarakat dan sudah turun temurun. Proses gadai adat ini adalah pemberi gadai menyerahkan barang gadaiannya dalam hal ini lahan (sawah, kebun atau pekarangan) sebagai jaminan atas uang yang dipinjamnya. Dalam hal ini jaminan tersebut menjadi hak si penerima gadai untuk memanfaatkannya, sampai si pemberi gadai dapat mengembalikan uang yang dipinjamnya. Proses dari praktik gadai ini sangat sederhana, jarang kita jumpai bukti-bukti tertulis dari proses gadai; kalaupun ada cukup kuitansi yang menjelaskan bahwa si pemberi gadai telah menerima sejumlah uang tertentu dari si penerima gadai tanpa ada saksi yang jelas /tertera dalam kuitansi tersebut. Dalam transaksi tersebut juga tidak ada tanda tangan saksi yang ada pada saat terjadinya aqad gadai, semua dilakukan secara sederhana atas dasar saling percaya mempercayai dan kekeluargaan.

\section{Praktik Gadai Lahan dilihat dari Perspektif Islam.}

Praktik gadai yang dilakukan oleh masyarakat yang ada di Kecamatan Lingsar Kabupaten Lombok Barat dilihat dari sarat, rukun gadai sudah sesuai dengan sarat, rukun gadai menurut Islam. Namun apabila dilihat dari aqad gadai antara pemeberi gadai dan penerima gadai, belum Islami. Karena menurut Islam aqad gadai (yang dalam bahasa Arab di sebut dengan rahn) merupakan aqad tabarru'(sukarela), yaitu upaya tolong menolong dan saling membantu antar sesama manusia dalam keadaan kesulitan, dan bukan merupakan kegiatan yang mengharapkan keuntungan. Hal ini sesuai dengan firman Allah (QS alBaqarah [2] : 283). Dalam praktik gadai yang ada di masyarakat, penerima gadai selalu mengharapkan keuntungan yang sebesar-besarnya dengan memanfaatkan barang jaminan yang dimiliki oleh pemberi gadai tanpa ada batasan waktu, kecuali si pemberi gadai sudah dapat mengembalikan uang yang dipinjamnya.

\section{Tingkat Kesejahteraan al-Rahin (yang menyerahkan barang gadai)}

Sebagaian besar dari pemberi gadai (alrahin) yang ada di Kecamatan Lingsar Kabupaten Lombok Barat belum sejahtera dilihat dari perspektif Islam, karena belum mampu memenuhi kebutuhan dharuriyatnya (terutama hifzun-nafs)

Mereka selalu dihantui oleh perasaan yang tidak enak karena memikirkan uang pinjaman yang harus diembalikannya. Hal lain adalah ketika datang musim buahbuahan, mereka selalu menghabiskan waktu malamnya untuk melakukan ronda di kebun mereka. Sebagaiannya sudah mendapatkan kesejahteraan secara Islam, karena sudah terpenuhi kebutuhan dharuriyyat dan hajiyatnya.

\section{KESIMPULAN}

\section{Kesimpulan}

1. Sebagian besar petani melakukan praktik gadai lahan karena keterbatasan keuangan dan sebagaian lagi disebabkan oleh ketidak jujuran penggarapnya serta untuk mendapatkan modal usaha.

2. Praktik gadai yang ada di Kecamatan Lingsar lebih banyak diwarnai oleh adat yang merupakan kebiasaan yang turun temurun dari para pendahulunya.

3. Praktik gadai lahan yang ada di Kecamatan Lingsar sudah sesuai dengan ru-kun dan syarat gadai menurut Islam, namun kalau dilihat dari pemanfaatan barang jaminan belum sesuai dengan prinsip gadai menurut Islam, karena melahirkan ketidak-adilan antara al-rahin dan almurtahin.

4. Sebagaian besar dari pemberi gadai (al-rahin) yang ada di Kecamatan Lingsar belum sejahtera dilihat dari perspektif Islam, dan sebagaiannya sudah mendapartkan kesejahteraan 
secara Islam, karena sudah terpenuhi kebutuhan dharuriyyat dan hajiyatnya.

\section{Saran}

Adanya keterbatasan keuangan dan kebutuhan mendesak di masyarakat, diharapkan ada lembaga keuangan yang dapat memberikan bantuan pinjaman kepada masyarakat yang bersifat syari'ah (gadai syari'ah), sehingga masyarakat tidak jatuh pada praktik ribawi.

\section{DAFTAR PUSTAKA}

An Najah, Ahmad Zain, 2010, Hukum Memanfaatkan Sawah yang digadaikan, Makalah, $\mathrm{http} / \mathrm{www}$ ahmadzain.com/read/karya tulis.

Aropah, Muhammad Nur, 2014. Prinsip Keadilan dalam "Sandak" (gadai lahan) dan Dampaknya terhadap Kesejahteraan Petani di Kabupaten Lombok Timur. Thesis Magister IImu Ekonomi Pascasarjana Universitas Mataram, tidak dipublikasikan.

Herfika, Cahyusa Desmutya 2013, Analisis Komparasi Mekanisme Produk Kridit pada Pegadaian Konvensional dan Pembiayaan pada Pegadaian Syari'ah (Studi pada PT Pegadaian di Nganjuk dan Kediri).

Husain, Jauhar, Ahmad Al-Mursi, 2009, Maqashid Syari'ah, Penerbit AMZAH, Jakarta

Moleong, J. Lexy, 2007, Metodologi Penelitian Kualitatif, Edisi, Revisi, Penebit Remaja Rosdakarya, Bandung

Muflih, Muhammad, 2006. Perilaku Konsumen Dalam Perspektif IImu Ekonomi Islam, Penerbit PT. Rajagrafindo Prersada, Jakarta.

Munir, 2014. Praktik Gadai Sawah dan Implikasi Sosial Ekonomi )Studi Kasus di Desa Juruan Daya Kecamatan Batuputih Kabupaten Sumenep Madura), Artikel Jurnal Universitas Brawijaya.

Mustafa, Hasan, 2007, Perspektif Dalam Perilaku Sosial,Makalah

Purwadarminta, WJS, 1995, Kamus Bahasa Indonesia , Penerbit PN Balai Pustaka, Jakarta.

Pusat Pengkajian dan Pengembangan Ekonomi Islam, 2008, Ekonomi Islam, Universitas Islam Indonesia atas kerjasama dengan Bank Indonesia, Yogjakarta

Shihab, M. Quraish, 2002. Tafsair al-Misbah, Pesan, Kesan dan Keserasian Al-Qur'an, Penerbit Lentera Hati, Jakarta.

.Yuniar, Salmi Bahri, 2015, Perilaku Masyarakat dalam Praktik Gadai Speda Motor di Kecamatan Selong, Kabupaten Lombok Timur, Thesis Magister IImu Ekonomi Mataram. 